\title{
Foreword: Run, Sarah!
}

\author{
JEAN-LUC NANCY
}

F

or Sarah, writing was what it should be, or perhaps what it is for anyone when it is considered, not in its particular qualities of style or voice, but above all in its bare gesture, in its delineation, its tracing, or (as she used to say) its scratching, not to say its scribble. In other words, before being the inscription and transmission of a thought, it was an attestation of existence. It may be that those who write are especially, if not exclusively, those who must attest to an existence, whether their own or that of another (not that these can always be separated), whether through lack of being or excess (not that these can always be separated). Sarah wrote for her living, as we say of those who make it their profession, but in her case, over and above the profession, it was not just a question of ensuring a subsistence but of attesting to an existence.

One day, Sarah told me how her arm had shown a reaction - the skin red and irritated - after she had rested it on her Devenir-femme d'Auguste Comte. "How I somatize!" she said. But she meant two things at once, one superficial, emotive, and nervous, the other more important: I identify myself through my writing, in particular through this writing the becoming-woman of a philosopher and through him no doubt that of all philosophers, which is also my own becoming-philosopher, my incorporation of philosophy. In this book, she wrote, "It is not a question of my attempting here to reduce philosophy to pathology or system to biography. It is rather a certain relationship of system to life which interests me: to see, not what the work owes to life but what the work brings to life; to grasp how a philosophical system can take the place of délire" (Kofman 1978a, 41). What interests me in

Translation by Paul Patton. A French version of this essay appeared in Les Cahiers du grif (new series): 3, 1997, 29-32. 
Sarah's work, and what knitted much of the friendship between us, is this manner of relating "works" to "life," rather than the converse, and what followed from it: her interest in people rather than their productions, her estrangement from the play of roles in little public scenes. None of this meant that the works should not be taken into account, nor that her concern was not to be read, above all by her friends, just as she attentively read others.

But her primary concern, at least with her friends, was that she not be "read" in the sense of "assimilated" or "registered": it was rather that the other's reading return to her in the form of a story, with episodes, surprises, or comments. In the same way, she was interested in anecdotes in general; she said that they were "the equivalent of a touch which underlined the essential, the beauty, the one irrefutable thing, all that remained when the truth of the system had disappeared" (Kofman [1979] 1986b, 19). That is why I am recounting anecdotes about her. I cannot separate her from her anecdotes. This was her way of being absolutely faithful: forgetting nothing, not one "touch" on the part of her friends, since fidelity was for her the very course of life. Not "truth" but fidelity, the truth of fidelity, which has no final sense but the sense of its very course. Truth that returns to life and not the converse.

That writing relates to life, and relates it, does not mean the absence of thought nor even its secondary importance. It means that thought does not begin without this gesture of writing and also that, just as it is transmitted by it, so thought ends with this gesture. But also that "thought," finally, is caught up in life and relates to it, ending in it and therefore also capable of ending it: there is no life after thought. A life of thought is perhaps a life that does not already live enough, or that lives too much, or again, quite simply, it is a life that attests itself, inscribing that it took place.

In this gesture, therefore, an existence is attested. An existence, as a result, that is uncertain of itself, anxious for itself when it is not thereby attested. An existence that needs to have proof of its existence in this manner. This ontological argument states that writing demonstrates with its letters the necessity of the existence of its subject.

This gesture-make no mistake-is not only and not necessarily that of graphic writing nor that of literary writing. It is also that of spoken teaching, 
that which is called in French the course. Sarah was, as they say, a professor "from the heart." No doubt, preparing a course is by no means the same as writing a text. But Sarah paid scant consideration to the differences. Her books were often her courses, which is also a great philosophical tradition.

What there is of writing in a course must be in the nature of prose, in other words of the discourse that goes prorsus, straight ahead, proversus, turned toward the front (in opposition to transversus). It goes forward, from the front, without interruption: it has no thought of interruption, other than that which marks the end of the hour and which only interrupts in order to better ensure the continuity of the hours, week after week. It does not contract itself nor return itself versus: it makes no verse, or rather it only verses forward, always in the same direction. Its only concern is to run ahead of itself, to be delivered always further out in front. Its truth lies in its movement, not in its punctuation. Its truth is insatiable, the unappeasable course of the course, always a delivery ahead of itself.

Sarah would have been amused to learn (perhaps she knew) that Prorsa was a goddess of childbirth, Sarah who counted her books like so many children, she who wanted to make more of these children than her mother had made living children and who in fact made so many more. To make children: not to engender, which is a male affair and a question of signification, but to bear and give birth to, which is an uninterrupted course or uninterruption itself. A woman gives birth to her child throughout her life. It is not the emission of a signification; it is expression in Spinoza's sense. These were Sarah's only children - the books, the courses, the course of the books - but they were what she wanted and it was through them that she never left infancy, that she endlessly prolonged a course of infancy, not her own but an absolute infancy of the course of life. She, who had no children, was very attentive to the children of others. Once we had exchanged news of our profession, books, and health, she never failed to inform herself about exactly what had happened to my children, and she forgot no detail.

Sarah was small. She joked about her little-girl size. But she also said, "Little Sarah doesn't give up without a fight." And she readily said "my little" to her friends (to me, for example: "my little Jean-Luc").

Prose, therefore course: "It follows its course," as Blanchot said of philosophical discourse. But Blanchot said this with an anxiety turned toward the notorious, pressing, and almost insupportable necessity of this course. Sarah, for her part, took pleasure in the interminable. She was not mobi- 
lized by the infinitely and frighteningly old hidden beneath the murmur. She was mobilized by the incessantly new, like the child who tries out prattle. She saw no end to her discourse, her course, or her books. No doubt, in this way too she was like all of us, but more than others she gave herself to the course; she became almost indistinguishable from it. Not that she identified herself with the university, or even with teaching. I am trying to speak of a larger, more important course-her personal cante jondo. She did not stop with the work, with the definite and, as it were, definitive form of a book. She was keen to finish a book, but in order to publish it (to launch it into another course, another circulation) and immediately to begin another (if it had not begun already). No doubt this rhythm and practice was not peculiar to her. But she brought to it a particular determination and an always awakened haste. As though, truly, the thing to do was to continue, not to punctuate, to activate the subject rather than to pose the object: in short, praxis rather than poiesis.

What is this interminable praxis of the course? What does it want to say? Perhaps it wants to say no more than the want-to-say. Perhaps it wants to say a want-to-say with no other end than itself. In consequence, a "will to will"-but equally a will that, ultimately, no longer wants, that is no longer a "want to say" in the sense that Derrida gave to his translation of Husserl's bedeuten (and that Sarah did not fail to employ: see, for example, Kofman 1986c, 64). In other words, a want-to-say that does not aim at the production of a conclusion, the establishment of a thesis, the jouissance of a signification. A "will to will" that would not be a "will to power" (if such may be conceived).

Sarah wrote little by way of conclusion to her books. Comparing final pages, we see that they are more like provisional interruptions than conclusions. Or she would write, "By way of conclusion, let us therefore leave the last word to laughter." Or she would conclude as though reporting, dating, and even multiply dating the end of her writing ("Terminating this book today, $25^{\text {th }}$ of September, the day of Yom Kippur," a Jewish joke that ends with "You recommence already?"). How can we not hear Sarah laughing at her own conclusion, by way of conclusion, because she knows that she has already begun another book, the rest of the course (perhaps Paroles suffoquées, which appeared the following year).

This want-to-say is aimed more at the linkage of motifs, the connection of arguments, the production of documents, the continuous embedding of words and reasons, the indeterminate openness, and the floating of a significance. In Levinasian terms, which were hardly Sarah's, the "to say" rather than the "said." Could there be something of a Jewish voice in Sarah? Recital and commentary, a writing of the biblia, always in the indefinite 
plural? But Sarah was Jewish in the very manner that she attributed to Freud (and that was not without Levinasian and Blanchotian resonance): "If, after having written Jokes and Their Relation to the Unconscious, Freud burned his collection of Jewish jokes, renounced his Jewish heritage and identity, it was to better generalize that Jewish 'identity,' to confer it on all humanity and, with this gift full of risk, cause it to lose forever its supposedly assured identity" (Kofman 1986c, 197). One page further on Sarah draws her laughing conclusion with a Jewish joke that makes fun of Jewish jokes.

A "generalized" Judaism, a Judaism in incessant course of dissemination and therefore also "Greek." Sarah's Nietzsche is the one from whom she liked to cite "the Jews[,] . . . a people firmly attached to life-like the Greeks and more than the Greeks" (Nietzsche 1982, 72; quoted in Kofman 1994c, 55). A philosopher's Judaism, in the sense that instead of being governed by the law of a calling (or rather, while also being governed by it), it seeks to maintain fidelity to the phenomenon or the phenomena. In this sense, this practice ties together the observance of a law of phenomena and the observation of the phenomenon of law. It can never be finished because the law does not protrude and because, symmetrically, the phenomenon is not the manifest given. Like the phenomenon, the law presents itself ceaselessly.

On the other hand, to want to say only the want-to-say can turn into a selfobsession, an energy of energy, a sterile and despairing "auto-nomie" (pure phenomenon of its own pure law). Sarah's discourse can no more be considered exempt than any other philosophical discourse. But this can also take a different turn: toward an always recommencing support for the possibility of meaning, for its very opening, or for its coupling, which is much more a condition of existence, infinitely more than any proposed conclusion or signification, founded or founding and sovereign in its order.

Linguists speak of a "phatic" function of language - in other words, of a function of simple opening and maintenance of the language exchange, the maintenance (entretien) of the exchange (entretien). Neither an apophatic (discourse of law) nor an apophantic (discourse of phenomena) but a phatic function: for example, when we say "yes," "huh," or "fine" only in order to punctuate and sustain the course of the dialogue (entretien). Weak words to sustain speech itself: they add nothing to the meaning, they do not connect, they hold open the place of speech. Sarah liked to speak; she insisted on the necessity of dialogue: "We must talk," "We haven't talked for ages," "So, tell me about your holiday." 
In this sense, philosophy is responsible for the phatic function of the entire discourse of meaning-I mean for nonmythical discourse, for what does not itself produce its object but is produced in indefinite pursuit of "the thing itself," always already there, but never here. Philosophy maintains the opening of meaning. In other words, it does not allow sense to be deposited (nor to rest); it does not allow it to close in upon itself. When it does close the result is ideology (Camera obscura, inversion of the image), nonthought, when neither call to be heard nor phenomenon to save. The opening of sense is truth.

Truth, not finality. Sarah did not write under the impetus of an end: neither goal nor achievement, but so fleeting, always one foot in the next book. If she shared with her time the jubilation of endless interpretations and the multiplication of truths, this was against the backdrop of a more remote and severe truth, the name of which is necessity. She speaks of herself when she writes, "Thus, for Empedocles as for Freud there is no finality: a necessity reigns which merges into the repetition of the same in difference" (Kofman 1991a, 50). Sarah had the somewhat rare sense of sober necessity, without the grandiloquence of destiny and equally without bitterness: just a touch between sadness and joy. It is in this tone that she finally wrote on the first page of Rue Ordener, Rue Labat: "Maybe all my books have been the detours required to bring me to write about 'it'" (Kofman 1996, 3).

What "it"? In fact, "who," or rather, neither exactly the one nor the other: neither her pen nor her father, but a "same" to which she felt "obligated." Repetition of the same: not the catatonia of a "self" that withdraws into itself, but rehearsal (répétition) in the theatrical sense-an essay, sketch, or repetition of propositions that must each time be displaced and fashioned, "winding paths" that lead straight ahead. Attempts at identification for an identity always to come, or rather always to return from the immemorial. Attempts at the unidentifiable, not unlike the motifs of Lacoue-Labarthe, who wrote in a text on Artaud dedicated "to the memory of Sarah": "To write is to say how one dies. And it is thought itself" (Lacoue-Labarthe 1995). There is perhaps some Artaud in Sarah. For example, I believe I can hear her in this sentence: "To practice metaphysics is to undertake the meta, to add something extra to the immediate and rudimentary rusticity of one's being, not to raise oneself to the great universal conceptual ideas which leave the physical behind and give only the meta and nothing else" (Artaud 1956, 177)

But finally, who, Sarah? She wrote apropos of Nietzsche: "But who 'himself'? The Nietzsche that he would 'become[,]' ... the promise that he represented?... But to say of someone that he promises is also to declare that 
he has not yet arrived at that which 'he' presages" (Kofman 1993a, 165). Sarah herself was perpetually suspended between her necessarily unfulfilled promise and her assurance, which was nothing other than that of "it," in other words, that of a primary errancy no less buried than the coming of the promise, that of an Unheimlichkeit of childhood in its entirety.

It is in this sense that she was a little girl who had to and was able to fashion for herself the identity of she who must constantly replay who she is - if that may be called "being"-constantly put it into play, try it differently. At once opinionated, stubborn, obstinate, never giving up. Sometimes that led to conflict. But this she sought only to end, on condition that she was recognized, not necessarily as being right, but as existing, and on condition that it was not she who was denied (and, for example, that I had not sought to poison her by allowing Trilling to smoke a cigar during a meeting).

To replay constantly, to revise the interpretation, to try another perspective, to be in the course of interminable analysis. Sarah represented this allegory: "Interminable Analysis Leaning over the Troubling Strangeness of Writing." But this allegory transforms itself into "Interminable Writing of Analytic Strangeness." Sarah never ceased to analyze the father of analysis and, in particular, to show how he attacks the woman in order to "fix and freeze her definitively in a type that corresponds with his 'ideal of femininity' " (Kofman 1985a, 222). A "type": did Sarah pay attention to the everyday sense of the word? She would have liked to laugh at it. ("Un type" is French slang for "guy.")

The woman, of course, is Sarah "herself" (once again, she would not have omitted the quotation marks). She is the one who runs throughout the analysis; she is the analysis "itself," the analysis of the analysis, the one who practices the "impossible profession" of analysis: "The plasticity of the 'ends' of the analytic profession makes of it more than a determinate technique, a sort of game with variable rules, adjusted to the temperament or to the underlying preferences of each player" (Kofman $1983 \mathrm{~b}, 13$ ). Her own rules, and her temperament, called for the interminable course of words, the unattainable infancy of meaning: "I spent my time reading everything anyone brought me: from the Vermot Almanach to Life of the Ants by Maeterlinck. In a notebook I kept a list of the words I didn't understand and looked up their meanings in the dictionary" (Kofman 1996, 76). There are those, male or female, who seek models in books, who only stop 
at certain chosen voices, and there are those, male or female, who seek an infinite renewal of meaning, an analysis more interminable than any turning over of the past.

With Sarah, the analysis of analysis - interpretation and dissolutioncomes with its identification: it is the name of Nietzsche, in other words the one whom, along with Freud, Sarah analyzed and commented upon the most. Their two names run from one end to the other of her books, and the dedication to Pourquoi rit-on? is itself a program, moreover a difficult one: "with all my wishes for great Freudian if not Nietzschean laughter." The name of Nietzsche is the name of the master of the fiction of a "becoming himself" (Kofman 1993a, 165). He becomes himself in becoming "all the names of history." Sarah wants to lend herself to the play of all the names of Nietzsche; she espouses this plasticity, but she mixes with it the "becoming-woman" of all those names as the truth of every philosopher. It is as though all these names become a single name once more, Sarah, name of a woman or woman-name that names the plasticity of all the others. "Ecce Mulier Sarah," she wrote on my copy of Explosions I, and perhaps on others.

Neither a "philosopher" nor a "woman philosopher" but rather the woman for every philosopher, the philosophers' "rival" (Kofman $19^{8} 5^{\mathrm{a}}$, 222) but also the vita of their truth and their logic (Kofman [1979] 1986b, 223), their mother, their sister, and their lover, or rather, finally, philosophy "itself," that which makes fun of philosophy, or goes infinitely beyond it, or even goes without it, and embarks it upon a course more obscure and troubled than any discourse, but also more bare and more alive.

In other words, more mortal. The certainty of necessity is also that of a "text dominated by an investigation which is not, at any moment, complete without being immediately invalidated: in it the work of Eros is always undermined by the silent activity of the death instincts" (Kofman $1991 \mathrm{~b}, 121$ ). If speech does not accumulate a capital of significations, it brings forth that which must in the end suffocate it. It becomes itself the desire to have done with its own course. When Sarah used to say, toward the last days, that she could no longer even read, she was not giving a sign, an effect of something else: she was pointing to the thing itself. No longer to read (but also, for Sarah, no longer to listen to music, no longer to see paintings or films), no longer to write, no longer to live. She said to me, "Look, I read this book and already I can't recall what is in it." The next 


\section{[xvi] Jean-Luc Nancy}

moment, I proved her wrong and she laughed, once again, a little. That was at her place, that last time, with Alexandre. It was the course stopped, interrupted with no possibility of resumption, or the same course finally precipitated clearly into its endlessness, into its insupportable absence of ending. A sort of clear madness that looks straight ahead into the truth and sees that it sees nothing there and that this cannot be said, nor can that which is affirmed in it (or that which is promised?). But it sees that an uninterrupted fidelity can nevertheless be spoken, in a voice of extreme suffering. As a result I say it anyway (seeing her again already on her way, frozen, and knowing that I will not make her laugh): run, Sarah! 